Tropical Journal of Pharmaceutical Research May 2017; 16 (5): 1147-1155

ISSN: $1596-5996$ (print); 1596-9827 (electronic)

(C) Pharmacotherapy Group, Faculty of Pharmacy, University of Benin, Benin City, 300001 Nigeria.

All rights reserved.

Available online at http://www.tjpr.org

Original Research Article

http://dx.doi.org/10.4314/tjpr.v16i5.24

\title{
Synthesis of some quinoline-pyrazoline-based naphthalenyl thiazole derivatives and their evaluation as potential antimicrobial agents
}

\author{
Mohd Imran ${ }^{1 \star}$, Mohammed Afroz Bakht ${ }^{2}$, Abdul Samad $^{2}$ and Abida ${ }^{1}$ \\ ${ }^{1}$ Department of Pharmaceutical Chemistry, Faculty of Pharmacy, Northern Border University, Rafha, 91911, PO Box 840, Saudi \\ Arabia, ${ }^{2}$ Department of Pharmaceutical Chemistry, College of Pharmacy, Prince Sattam Bin Abdulaziz University, PO Box \\ 173, Al-Kharj 11942, Saudi Arabia
}

*For correspondence: Email: imran_inderlok@yahoo.co.in; Tel: +966599577945

Sent for review: 14 November 2016

Revised accepted: 16 April 2017

\begin{abstract}
Purpose: To prepare and evaluate some quinoline-pyrazoline-based naphthalenyl thiazole derivatives as antimicrobial agents.

Methods: Some quinoline-pyrazoline-based naphthalenyl thiazoles (5a-5e and 6a-6e) were prepared by reacting 5-(2-chloroquinolin-3-yl)-3-substitutedphenyl-4,5-dihydro-1H-pyrazole-1-carbothiamides (4a4e) with 2-bromo-1-(1-naphthyl)ethanone and 2-bromo-1-(2-naphthyl)ethanone, respectively. Fourier transform infra-red (FTIR), ${ }^{13} \mathrm{C}$-Nuclear magnetic resonance $\left({ }^{13} \mathrm{C}\right.$-NMR), ${ }^{1} \mathrm{H}$-Nuclear magnetic resonance $\left({ }^{1} \mathrm{H}\right.$-NMR), elemental analysis, and mass spectrometry were used to elucidate and confirm the chemical structures of the target compounds. Serial plate dilution technique was used to evaluate the antimicrobial activity of the title compounds using ketoconazole and ofloxacin as standards, and their minimum inhibitory concentrations (MIC) were determined.

Results: $A$ total of ten compounds, (5a-5e) \& (6a-6e) were prepared. Compound $6 \boldsymbol{d}(R=4-F$, naphthalen-2-yl derivative) exhibited antimicrobial activities that were higher than those of the standard drug (ofloxacin) against $S$. aureus (MIC $=25 \mu \mathrm{g} / \mathrm{mL}, p<0.05$ ), S. epidermidis (MIC $=25 \mu \mathrm{g} / \mathrm{mL}, p<$ $0.0001), K$. pneumonia (MIC $=25 \mu \mathrm{g} / \mathrm{mL}, p<0.0001), P$. vulgaris ( $M I C=25 \mu \mathrm{g} / \mathrm{mL}, p<0.0001$ ) and $P$. citrinum (MIC $=25 \mu \mathrm{g} / \mathrm{mL}, p<0.0001)$. Compound $5 \boldsymbol{d}(R=4-F$, naphthalen-1-yl derivative) displayed higher antifungal activity than ketoconazole against $C$. albicans (MIC $=25 \mu \mathrm{g} / \mathrm{mL}, p<0.0001)$.

Conclusion: The naphthalen-2-yl derivatives (6a-6e) are superior antimicrobial agents as compared to the naphthalen-1-yl derivatives (5a-5e) and the presence of 4-F substituent in $6 d$ and $5 d$ is essential for stronger antimicrobial activity. The compound $\mathbf{6} \boldsymbol{d}$ needs further investigations related to its safety and efficacy.
\end{abstract}

Keywords: Quinoline, Pyrazoline, Thiazole, Antibacterial, Antifungal, Structure-activity relationship

Tropical Journal of Pharmaceutical Research is indexed by Science Citation Index (SciSearch), Scopus, International Pharmaceutical Abstract, Chemical Abstracts, Embase, Index Copernicus, EBSCO, African Index Medicus, JournalSeek, Journal Citation Reports/Science Edition, Directory of Open Access Journals (DOAJ), African Journal Online, Bioline International, Open-J-Gate and Pharmacy Abstracts

\section{INTRODUCTION}

Antimicrobial resistance (AMR), a current global concern for human health, is mostly related to the irrational use of antibiotics [1,2]. This has caused the emergence of multidrug-resistant (MDR) pathogens and has also made treatment of many bacterial infections difficult. It is reported that the infections caused by the antibiotic resistant bacteria kill about twenty thousand patients annually in the USA and also leads to economic loss [3]. The cases of AMR bacterial infections are also increasing in the Kingdom of Saudi Arabia due to irrational use of antibiotics as well as due to the socio-economic and 
demographic characteristics of Saudi, non-Saudi and pilgrim population [4-7]. Another factor contributing to the development of AMR is failure to discover new antimicrobial agents [8-10]. Accordingly, there is a need to take remedial actions with respect to the issues related to the antimicrobial resistance.

Thiazolyl heterocycles, quinolinyl heterocycles, and pyrazolinyl heterocycles have an important place in medicinal chemistry. Recently, review articles mentioning the usefulness of thiazolyl heterocycles [11,12], quinolinyl heterocycles $[13,14]$, and pyrazolinyl heterocycles $[15,16]$ as analgesic, anti-inflammatory, antibacterial, antifungal, antiviral, antiparasitic, anticoagulant, anti-Parkinson's Disease, anticancer, antioxidants, antidiabetic, CNS depressant, and antimalarial have been published. Recently, thiazolyl pyrazoline derivatives (I) and quinolinylpyrazoline-based thiazole derivatives (II) have been postulated as templates for the development of new antimicrobial agents $[17,18]$ (Figure 1).

On the basis of these findings and our continued search for novel heterocyclic antimicrobial agents [19-21], some quinoline-pyrazoline-based naphthalenyl thiazoles (5a-5e and 6a-6e) were synthesized and evaluated as antimicrobial agents.

\section{EXPERIMENTAL}

\section{Chemistry}

Open capillary tube method was used to determine the melting points of the synthesized compounds which are uncorrected. The FTIR spectra in $\mathrm{KBr}$ were generated using a $5 \mathrm{PC}$ FTIR spectrophotometer (Nicolet, Browser Morner, USA). The ${ }^{1} \mathrm{H}$-NMR and ${ }^{13} \mathrm{C}$-NMR spectra were generated using a DRX-300 FT NMR (Germany, Bruker) spectrophotometer. Mass spectra were generated on a mass spectrometer $(70 \mathrm{eV}$, JeolJMS-D-300, Japan). The $\mathrm{C}, \mathrm{H}$ and $\mathrm{N}$ were analysed satisfactorily for the titled compounds within the range of $\pm 0.4 \%$ of theoretical value. Completion of reaction was monitored by checking on pre-coated commercial thin layer chromatography plates, by using ultra-violet cabinet for visualization purpose. The solvent system to run these plates consisted of a mixture of toluene, ethyl acetate and formic acid (5:4:1). Only analytical grade reagents were used for the present work. Ofloxacin was procured from Sun Pharmaceuticals, India, as a gift sample. Ketoconazole was procured from Cipla, India, as a gift sample. Figure 2 provides the route of synthesis of the desired compounds (5a-5e) \& (6a-6e).<smiles>[X]c1ccc(C2=NN(c3nc(-c4cc5cc([R])ccc5oc4=O)cs3)C(O)(C(F)(F)F)C2)cc1</smiles><smiles>[R]CCC(C1=NN(c2nc(-c3cccc4ccccc34)cs2)C(c2cc3ccccc3nc2Cl)C1)c1ccccc1</smiles><smiles>[R1]CC(C1=NN(c2nc(-c3ccc4ccccc4c3)cs2)C(c2cc3ccccc3nc2Cl)C1)c1ccccc1</smiles>

(5a-5e)

$$
\mathrm{R}=\mathrm{H}, \mathrm{Cl}, \mathrm{Br}
$$

(6a-6e)

$$
\mathrm{R}_{1}=2-\mathrm{Cl}, 2-\mathrm{F}, 3-\mathrm{F}, 4-\mathrm{F}, 4-\mathrm{NO}_{2}
$$

Figure 1: Structures of the postulated antimicrobial lead compounds (I and II), and proposed ones to be synthesized (5a-5e and 6a-6e) 


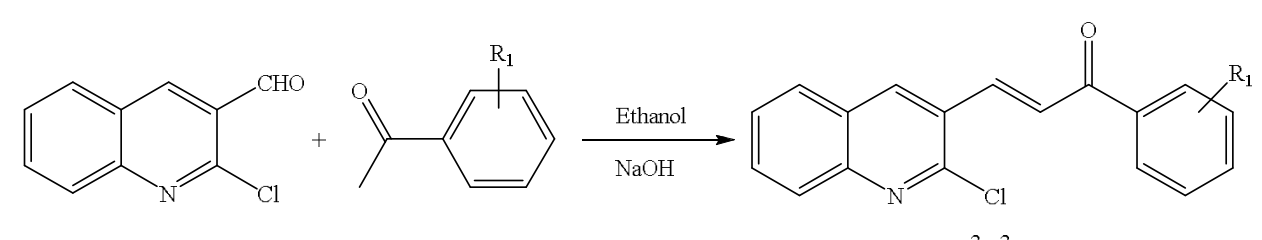<smiles>[R3]CC(C)C(=O)c1cccc2ccccc12</smiles>

Figure 2: General procedure for the synthesis of compounds 5a-5e \& 6a-6e

The compounds $(\mathbf{4 a}-\mathbf{4 e})$ were prepared according to the method provided in the literature [18]. The compounds 2-bromo-1-(1-naphthyl) ethanone and 2-bromo-1-(2-naphthyl)ethanone were prepared according to the method provided in our earlier report [22].

Preparation of 2-(3-substitutedphenyl-5-(2chloroquinolin-3-yl)-4,5-dihydro-1 H-pyrazol-1yl)-4-(naphthalen-1-yl) thiazole (5a-5e)

A mixture of the appropriate compound (4a-4e) (0.01 mole), 2-bromo-1-(1-naphthyl)ethanone (0.01 mole) in $30 \mathrm{ml}$ of ethanol $(99.9 \%)$ was reflux for about 4 to $6 \mathrm{~h}$. The mixture was cooled, the solid was separated, washed with $10 \%$ ethanol, and recrystallized from ethanol.

Preparation of 2-(3-substitutedphenyl-5-(2chloroquinolin-3-yl)-4,5-dihydro-1H-pyrazol-1yl)-4-(naphthalen-2-yl)thiazole (6a-6e)

A mixture of the appropriate compound (4a-4e) (0.01 mole), 2-bromo-1-(2-naphthyl)ethanone (0.01 mole) in $30 \mathrm{ml}$ of ethanol $(99.9 \%)$ was reflux for about 4 to $6 \mathrm{~h}$. The mixture was cooled, the solid was separated, washed with $10 \%$ ethanol, and recrystallized from ethanol.

\section{Antimicrobial activity}

The compounds (5a-5e) \& (6a-6e) were screened for their antimicrobial activity using the serial plate dilution technique [23-24] against five Gram-positive bacteria; five Gram-negative bacteria; and five fungi. The procedure provided in our earlier reports [19-21] was followed and the minimum inhibitory concentrations (MICs) values were also determined with respect to ketoconazole and ofloxacin.

\section{Statistical analysis}

The data presented in Table 1, Table 2 and Table $3(n=6)$ were analyzed using one-way analysis of variance along with Dunnett's comparison test in comparison to control group and standard group using GraphPad Prism version 5.00 for Windows (GraphPad Software (www.graphpad.com). The results were considered significantly different at $p<0.05$. 
Table 1: Antibacterial activity of compounds 5a-5e and 6a-6e against Gram-positive bacteria

\begin{tabular}{lccccc}
\hline Compound & \multicolumn{4}{c}{ Activity (\%) with respect to standard drug (ofloxacin) } \\
\cline { 2 - 6 } & S. aureus & E. faecalis & S. epidermidis & B. subtilis & B. cereus \\
\hline $\mathbf{5 a}$ & $67.38^{\mathrm{a}}$ & $47.22^{\mathrm{a}}$ & $63.39^{\mathrm{a}}$ & $55.88^{\mathrm{a}}$ & $54.79^{\mathrm{a}}$ \\
$\mathbf{5} \boldsymbol{b}$ & $60.05^{\mathrm{a}}$ & $61.41^{\mathrm{a}}$ & $53.35^{\mathrm{a}}$ & $59.22^{\mathrm{a}}$ & $63.34^{\mathrm{a}}$ \\
$\mathbf{5}$ & $73.84^{\mathrm{a}}$ & $62.89^{\mathrm{a}}$ & $66.98^{\mathrm{a}}$ & $74.54^{\mathrm{a}}$ & $89.91^{\mathrm{a}}$ \\
$\mathbf{5} \boldsymbol{a}$ & $85.97^{\mathrm{a}}$ & $79.18^{\mathrm{a}}$ & $94.09^{\mathrm{a}}$ & $91.23^{\mathrm{a}}$ & $99.10^{\mathrm{a}}$ \\
$\mathbf{5}$ & $62.38^{\mathrm{c}}$ & $47.51^{\mathrm{a}}$ & $45.98^{\mathrm{a}}$ & $50.21^{\mathrm{a}}$ & $57.71^{\mathrm{a}}$ \\
$\mathbf{6} \boldsymbol{a}$ & $72.79^{\mathrm{a}}$ & $65.61^{\mathrm{a}}$ & $69.65^{\mathrm{a}}$ & $57.50^{\mathrm{a}}$ & $67.42^{\mathrm{a}}$ \\
$\mathbf{6} \boldsymbol{b}$ & $58.83^{\mathrm{a}}$ & $50.50^{\mathrm{a}}$ & $60.51^{\mathrm{a}}$ & $59.31^{\mathrm{a}}$ & $74.22^{\mathrm{a}}$ \\
$\mathbf{6}$ & $82.73^{\mathrm{c}}$ & $82.49^{\mathrm{a}}$ & $90.44^{\mathrm{a}}$ & $80.57^{\mathrm{a}}$ & $89.91^{\mathrm{a}}$ \\
$\mathbf{6 d}$ & $100.60^{\mathrm{c}}$ & $92.01^{\mathrm{a}}$ & $101.37^{\mathrm{a}}$ & $91.85^{\mathrm{a}}$ & $99.46^{\mathrm{a}}$ \\
$\mathbf{6 e}$ & $62.99^{\mathrm{a}}$ & $44.50^{\mathrm{b}}$ & $39.18^{\mathrm{a}}$ & $46.50^{\mathrm{a}}$ & $53.86^{\mathrm{a}}$ \\
Ofloxacin & $100.0 \%^{\mathrm{a}}$ & $100.0 \%^{\mathrm{a}}$ & $100.00^{\mathrm{a}}$ & $100.00^{\mathrm{a}}$ & $100.00^{\mathrm{a}}$ \\
Control & 0 & 0 & 0 & 0 & 0 \\
\hline
\end{tabular}

$a=p<0.0001$ with respect to the control and/or the standard; $b=p<0.0001$ with respect to the control and $p$ $<0.001$ as compared to the standard; $c=p<0.0001$ with respect to the control and $p<0.05$ with respect to the standard; $d=p<0.0001$ with respect to the control and $p>0.05$ as compared to the standard

Table 2: Antibacterial activity of compounds 5a-5e and $6 a-6 e$ against Gram-negative bacteria

\begin{tabular}{lccccc}
\hline Compound & \multicolumn{5}{c}{ Activity (\%) with respect to the standard drug (ofloxacin) } \\
\cline { 2 - 6 } & $\boldsymbol{E}$. coli & P. aeruginosa & K. pneumonia & B. bronchiseptica & P. vulgaris \\
\hline $\mathbf{5 a}$ & $75.65^{\mathrm{a}}$ & $72.27^{\mathrm{a}}$ & $87.14^{\mathrm{a}}$ & $68.15^{\mathrm{a}}$ & $76.24^{\mathrm{a}}$ \\
$\mathbf{5 b}$ & $70.59^{\mathrm{a}}$ & $69.69^{\mathrm{a}}$ & $74.89^{\mathrm{a}}$ & $74.17^{\mathrm{a}}$ & $79.09^{\mathrm{a}}$ \\
$\mathbf{5} \boldsymbol{c}$ & $92.73^{\mathrm{a}}$ & $84.33^{\mathrm{a}}$ & $93.29^{\mathrm{a}}$ & $86.57^{\mathrm{a}}$ & $90.30^{\mathrm{a}}$ \\
$\mathbf{5} \boldsymbol{d}$ & $96.57^{\mathrm{a}}$ & $99.75^{\mathrm{a}}$ & $99.16^{\mathrm{a}}$ & $94.33^{\mathrm{a}}$ & $99.69^{\mathrm{a}}$ \\
$\mathbf{5 e}$ & $76.44^{\mathrm{b}}$ & $72.48^{\mathrm{a}}$ & $89.98^{\mathrm{a}}$ & $68.53^{\mathrm{a}}$ & $70.06^{\mathrm{a}}$ \\
$\mathbf{6 a}$ & $68.62^{\mathrm{a}}$ & $70.47^{\mathrm{a}}$ & $69.58^{\mathrm{a}}$ & $79.42^{\mathrm{a}}$ & $67.19^{\mathrm{a}}$ \\
$\mathbf{6 b}$ & $78.09^{\mathrm{a}}$ & $77.76^{\mathrm{a}}$ & $72.11^{\mathrm{a}}$ & $65.43^{\mathrm{b}}$ & $77.34^{\mathrm{c}}$ \\
$\mathbf{6 c}$ & $82.95^{\mathrm{a}}$ & $87.36^{\mathrm{b}}$ & $87.57^{\mathrm{a}}$ & $88.34^{\mathrm{a}}$ & $90.85^{\mathrm{a}}$ \\
$\mathbf{6 d}$ & $98.44^{\mathrm{a}}$ & $98.70^{\mathrm{a}}$ & $100.30^{\mathrm{a}}$ & $97.34^{\mathrm{a}}$ & $103.45^{\mathrm{a}}$ \\
$\mathbf{6 e}$ & $64.67^{\mathrm{a}}$ & $67.98^{\mathrm{a}}$ & $81.70^{\mathrm{a}}$ & $81.61^{\mathrm{b}}$ & $85.70^{\mathrm{d}}$ \\
Ofloxacin & $100.00^{\mathrm{a}}$ & $100.00^{\mathrm{a}}$ & $100.00^{\mathrm{a}}$ & $100.00^{\mathrm{a}}$ & $100.00^{\mathrm{a}}$ \\
Control & 0 & 0 & 0 & 0 & 0
\end{tabular}

$a=p<0.0001$ with respect to the control and/or the standard; $b=p<0.0001$ with respect to the control and $p$ $<0.001$ with respect to the standard; $c=p<0.0001$ with respect to the control and $p<0.05$ with respect to the standard; $d=p<0.0001$ with respect to the control and $p>0.05$ with respect to the standard

Table 3: Antifungal activity data of compounds 5a-5e and 6a-6e against fungi

\begin{tabular}{lccccc}
\hline Compound & \multicolumn{5}{c}{ Activity (\%) with respect to standard drug (ketoconazole) } \\
\cline { 2 - 6 } & C. albicans & A. niger & A. flavus & M. purpureous & P. citrinum \\
\hline 5a & $68.21^{\mathrm{a}}$ & $85.80^{\mathrm{a}}$ & $82.97^{\mathrm{a}}$ & $72.80^{\mathrm{a}}$ & $79.08^{\mathrm{a}}$ \\
5b & $79.76^{\mathrm{a}}$ & $80.71^{\mathrm{a}}$ & $84.22^{\mathrm{c}}$ & $77.71^{\mathrm{a}}$ & $85.65^{\mathrm{a}}$ \\
$\mathbf{5 c}$ & $93.92^{\mathrm{a}}$ & $89.49^{\mathrm{a}}$ & $91.26^{\mathrm{c}}$ & $86.18^{\mathrm{a}}$ & $89.05^{\mathrm{a}}$ \\
$\mathbf{5 d}$ & $106.16^{\mathrm{a}}$ & $96.50^{\mathrm{a}}$ & $96.33^{\mathrm{a}}$ & $96.07^{\mathrm{a}}$ & $96.69^{\mathrm{a}}$ \\
5e & $82.40^{\mathrm{a}}$ & $83.85^{\mathrm{a}}$ & $80.88^{\mathrm{b}}$ & $78.51^{\mathrm{a}}$ & $84.72^{\mathrm{a}}$ \\
6a & $71.57^{\mathrm{a}}$ & $76.25^{\mathrm{a}}$ & $65.37^{\mathrm{d}}$ & $74.71^{\mathrm{a}}$ & $91.09^{\mathrm{a}}$ \\
6b & $87.48^{\mathrm{a}}$ & $93.52^{\mathrm{b}}$ & $89.14^{\mathrm{b}}$ & $89.71^{\mathrm{a}}$ & $93.72^{\mathrm{a}}$ \\
6c & $91.99^{\mathrm{a}}$ & $94.48^{\mathrm{a}}$ & $93.96^{\mathrm{b}}$ & $92.06^{\mathrm{a}}$ & $94.02^{\mathrm{a}}$ \\
6d & $99.93^{\mathrm{a}}$ & $96.50^{\mathrm{a}}$ & $96.04^{\mathrm{a}}$ & $95.48^{\mathrm{a}}$ & $103.80^{\mathrm{a}}$ \\
6e & $85.46^{\mathrm{a}}$ & $86.76^{\mathrm{a}}$ & $92.32^{\mathrm{a}}$ & $84.75^{\mathrm{b}}$ & $87.25^{\mathrm{a}}$ \\
Ketoconazole & $100.00^{\mathrm{a}}$ & $100.00^{\mathrm{a}}$ & $100.00^{\mathrm{a}}$ & $100.00^{\mathrm{a}}$ & $100.00^{\mathrm{a}}$ \\
Control & 0 & 0 & 0 & 0 & 0 \\
\hline
\end{tabular}

$a=p<0.0001$ with respect to the control and/or the standard; $b=p<0.0001$ with respect to the control and $p$ $<0.001$ with respect to the standard; $c=p<0.0001$ with respect to the control and $p<0.05$ with respect to the standard; $d=p<0.0001$ with respect to the control and $p>0.05$ with respect to the standard 


\section{RESULTS}

\section{Chemistry}

The synthetic route for the preparation of the compounds (5a-5e) \& $(\mathbf{6 a}-\mathbf{6 e})$ is depicted in Scheme 1. The compounds (4a-4e) were synthesized according to the method described in the literature [18]. The compounds (5a-5e) were prepared by reacting compounds $(\mathbf{4 a}-\mathbf{4} \mathbf{e})$ with 2-bromo-1-(1-naphthyl)ethanone using ethanol as solvent. Similarly, the compounds (6a6e) were prepared by reacting compounds (4a4e) with 2-bromo-1-(2-naphthyl)ethanone using ethanol as solvent.

These compounds were characterized by their different melting points with respect to their respective starting materials, different $R_{f}$ values in a particular solvent system, spectral data (IR, ${ }^{13} \mathrm{C}-\mathrm{NMR}$ and ${ }^{1} \mathrm{H}$-NMR) and elemental analysis. The IR spectra of the compounds (5a-5e) \& (6a6e) showed IR peaks for $\mathrm{C}=\mathrm{N}$ group ranging from $1575 \mathrm{~cm}^{-1}$ to $1580 \mathrm{~cm}^{-1}$; and for $\mathrm{C}=\mathrm{C}$ group ranging from $1535 \mathrm{~cm}^{-1}$ to $1540 \mathrm{~cm}^{-1}$. It also displayed characteristic IR peak of C-S group of thiazole moiety ranging from $1106 \mathrm{~cm}^{-1}$ to 1112 $\mathrm{cm}^{-1}$. The ${ }^{1} \mathrm{H}$-NMR spectra of the compounds $(5 \mathbf{a}-5 \mathbf{e}) \&(6 \mathbf{a}-6 \mathbf{e})$ exhibited characteristic signals for the methylene protons $\left(\mathrm{C}_{4}-\mathrm{H}\right.$ protons) of pyrazoline ring. One proton of the methylene group of pyrazoline ring appeared as doublet at ( $\delta$ 3.59-3.65) and another proton also appeared as doublet $(\delta 3.87-3.91)$.

The $\mathrm{C}_{5}-\mathrm{H}$ proton of the pyrazoline ring appeared as doublet at $\delta 5.16-5.21$. The ${ }^{1} \mathrm{H}$-NMR spectra also showed characteristic signals as multiplets at $\delta 7.10-8.15$ for aromatic protons. The ${ }^{13} \mathrm{C}$ NMR spectra also supported the assigned number of carbon atoms. It showed characteristic signal at $\delta 37.0-37.5$ due to the methylene carbon $\left(\mathrm{C}_{4}\right)$ of the pyrazoline ring and at $\delta 53.4$ due to the methine carbon $\left(\mathrm{C}_{5}\right)$ of the pyrazoline ring. The signals at about $\delta 166.3-166.6$ arose due to the $\mathrm{C}_{2}$ carbon of the thiazole ring. The mass spectra and the elemental analysis data for the compounds $(5 a-5 e) \&(6 a-6 e)$ were also in accordance with the assigned chemical structures.

The spectral data for the compounds (5a-5e) and $(6 \mathbf{a}-6 \mathbf{e})$ are provided below.

\section{2-(3-(0-chlorophenyl)-5-(2-chloroquinolin-3- yl)-4,5-dihydropyrazol-1-yl)-4-(naphthalen-1- yl) thiazole (5a)}

Yield: $55 \%$; m.p.: $192{ }^{\circ} \mathrm{C} ; \mathrm{R}_{\mathrm{f}}$ value: 0.71 ; IR (KBr): 1575, 1536, 1109; ${ }^{1} \mathrm{H}-\mathrm{NMR}$ (DMSO-d $\mathrm{d}_{6}$,
$400 \mathrm{MHz}) \delta$ ppm: $3.61(\mathrm{~d}, \mathrm{~J}=17 \mathrm{~Hz}, 1 \mathrm{H}), 3.89$ (d, $\mathrm{J}=17 \mathrm{~Hz}, 1 \mathrm{H}), 5.17(\mathrm{~d}, \mathrm{~J}=18 \mathrm{~Hz}, 1 \mathrm{H}), 7.15-8.10$ $(\mathrm{m}, 17 \mathrm{H}, \mathrm{Ar}-\mathrm{H}) ;{ }^{13} \mathrm{C}-\mathrm{NMR}$ (DMSO-d $\left.6,100 \mathrm{MHz}\right) \delta$ ppm: $37.0\left(\mathrm{C}_{4}\right.$ of the pyrazoline ring $), 53.4\left(\mathrm{C}_{5}\right.$ of the pyrazoline ring), $105.0\left(\mathrm{C}_{5}\right.$ of the thiazole ring), 121.1, 123.4, 124.3 (2C), 124.6, 125.0, $125.3,125.5,126.3$ (3C), 126.8, 127.9, 128.1, $128.3,128.6,128.9,130.4,130.7,132.2$ (2C), $135.2,138.6,143.4,145.8,149.7\left(C_{3}\right.$ of the pyrazoline ring), $149.9 \quad\left(\mathrm{C}_{5}\right.$ carbon of the quinoline ring), $166.5\left(\mathrm{C}_{2}\right.$ carbon of the thiazole ring); Mass (m/z): $550\left(\mathrm{M}^{+}, 100 \%\right), 551\left(\mathrm{M}^{+}+1\right)$, 276, 184, 138, 111, 92; Elemental Analysis $\left(\mathrm{C}_{31} \mathrm{H}_{20} \mathrm{C}_{12} \mathrm{~N}_{4} \mathrm{~S}\right)$ : Calcd.: $\mathrm{C}, 67.51 ; \mathrm{H}, 3.65 ; \mathrm{N}$, 10.15; Found: C, 67.51 ; H, 3.64; N, 10.16.

\section{2-(5-(2-chloroquinolin-3-yl)-3-(o- fluorophenyl)-4,5-dihydropyrazol-1-yl)-4- (naphthalen-1-yl)thiazole (5b)}

Yield: $60 \%$; m.p.: $210{ }^{\circ} \mathrm{C}$; $\mathrm{R}_{\mathrm{f}}$ value: 0.77; IR (KBr): 1578, 1539, 1111; ${ }^{1} \mathrm{H}-\mathrm{NMR}: 3.60$ (d, $\mathrm{J}=17 \mathrm{~Hz}, 1 \mathrm{H}), 3.90(\mathrm{~d}, \mathrm{~J}=17 \mathrm{~Hz}, 1 \mathrm{H}), 5.19$ (d, $\mathrm{J}=18 \mathrm{~Hz}, 1 \mathrm{H}), 7.13-8.11(\mathrm{~m}, 17 \mathrm{H}$, Ar- $\mathrm{H}) ;{ }^{13} \mathrm{C}-$ NMR: $37.5\left(\mathrm{C}_{4}\right.$ of the pyrazoline ring), $53.4\left(\mathrm{C}_{5}\right.$ of the pyrazoline ring), $105.0\left(\mathrm{C}_{5}\right.$ of the thiazole ring), 113.6, 116.2, 121.1, 122.4, 123.4, 124.3 (2C), 124.6, 125.0, 125.3, 125.5, 126.3 (3C), 127.9, $128.8(2 \mathrm{C}), 130.6,130.7,132.2,134.2$, 138.6, 143.4, 145.8, $149.7\left(\mathrm{C}_{3}\right.$ of the pyrazoline ring), $149.9\left(\mathrm{C}_{5}\right.$ carbon of the quinoline ring), 157.6 (Ar-C), $166.4\left(\mathrm{C}_{2}\right.$ carbon of the thiazole ring); Mass (m/z): $534\left(\mathrm{M}^{+}, 100 \%\right), 535\left(\mathrm{M}^{+}+1\right)$, 268, 179, 134, 107, 90; Elemental Analysis $\left(\mathrm{C}_{31} \mathrm{H}_{20} \mathrm{ClFN}_{4} \mathrm{~S}\right)$ : Calcd.: C, 69.59; H, 3.76; N, 10.46; Found: C, 69.56; H, 3.75; N, 10.45.

\section{2-(5-(2-chloroquinolin-3-yl)-3-(m- fluorophenyl)-4,5-dihydropyrazol-1-yl)-4- (naphthalen-1-yl)thiazole (5c)}

Yield: $60 \%$; m.p.: $222{ }^{\circ} \mathrm{C}$; $\mathrm{R}_{\mathrm{f}}$ value: 0.71 ; IR (KBr): 1580, 1540, 1106; ${ }^{1} \mathrm{H}-\mathrm{NMR}: 3.64$ (d, $J=17 \mathrm{~Hz}, 1 \mathrm{H}), 3.88(\mathrm{~d}, \mathrm{~J}=17 \mathrm{~Hz}, 1 \mathrm{H}), 5.21(\mathrm{~d}$, $\mathrm{J}=18 \mathrm{~Hz}, 1 \mathrm{H}), 7.16-8.13(\mathrm{~m}, 17 \mathrm{H}$, Ar- $\mathrm{H}) ;{ }^{13} \mathrm{C}-$ NMR: $37.4\left(\mathrm{C}_{4}\right.$ of the pyrazoline ring), $53.4\left(\mathrm{C}_{5}\right.$ of the pyrazoline ring), $105.0\left(\mathrm{C}_{5}\right.$ of the thiazole ring), 113.0, 115.8, 121.1, 121.8, 123.4, 124.3 (2C), 124.6, 125.0, 125.3, 125.5, 126.3 (3C), $127.9,128.4,128.9,130.7,132.2,133.6,134.2$, 138.6, 143.4, 145.8, $149.7\left(\mathrm{C}_{3}\right.$ of the pyrazoline ring), $149.9\left(\mathrm{C}_{5}\right.$ carbon of the quinoline ring), 161.0 (Ar-C), $166.5\left(C_{2}\right.$ carbon of the thiazole ring); Mass (m/z): $534\left(\mathrm{M}^{+}, 100 \%\right), 535\left(\mathrm{M}^{+}+1\right)$, 268, 179, 134, 107, 90; Elemental Analysis $\left(\mathrm{C}_{31} \mathrm{H}_{20} \mathrm{ClFN}_{4} \mathrm{~S}\right)$ : Calcd.: C, 69.59; H, 3.76; N, 10.46; Found: C: C, 69.51; H, 3.73; N, 10.43. 
2-(5-(2-chloroquinolin-3-yl)-3-(pfluorophenyl)-4,5-dihydropyrazol-1-yl)-4(naphthalen-1-yl)thiazole (5d)

Yield: $65 \%$; m.p.: $205{ }^{\circ} \mathrm{C}$; $\mathrm{R}_{\mathrm{f}}$ value: 0.74 ; IR (KBr): 1579, 1538, 1109; ${ }^{1} \mathrm{H}-\mathrm{NMR}: 3.59$ (d, $J=17 \mathrm{~Hz}, 1 \mathrm{H}), 3.89(\mathrm{~d}, \mathrm{~J}=17 \mathrm{~Hz}, 1 \mathrm{H}), 5.19(\mathrm{~d}$, $\mathrm{J}=18 \mathrm{~Hz}, 1 \mathrm{H}), 7.11-8.11(\mathrm{~m}, 17 \mathrm{H}$, Ar- $\mathrm{H}) ;{ }^{13} \mathrm{C}-$ NMR: $37.5\left(\mathrm{C}_{4}\right.$ of the pyrazoline ring $), 53.4\left(\mathrm{C}_{5}\right.$ of the pyrazoline ring), $105.2\left(\mathrm{C}_{5}\right.$ of the thiazole ring), $113.6(2 \mathrm{C}), 121.1,123.4,124.3$ (3C), $125.0,125.3,125.5,126.3$ (3C), 127.5 (2C), $127.9,128.9,130.0,130.7,132.2,134.2,138.6$, $143.4,145.8,149.7\left(C_{3}\right.$ of the pyrazoline ring $)$, $149.9\left(\mathrm{C}_{5}\right.$ carbon of the quinoline ring), 163.2, $166.3\left(\mathrm{C}_{2}\right.$ carbon of the thiazole ring); Mass $(\mathrm{m} / \mathrm{z}): 534\left(\mathrm{M}^{+}, 100 \%\right), 535\left(\mathrm{M}^{+}+1\right), 268,179$, 134, 107, 90; Elemental Analysis $\left(\mathrm{C}_{31} \mathrm{H}_{20} \mathrm{ClFN}_{4} \mathrm{~S}\right)$ : Calcd: $\mathrm{C}, 69.59 ; \mathrm{H}, 3.76 ; \mathrm{N}$, 10.46; Found: C, 69.56; H, 3.76; N, 10.44.

\section{2-(5-(2-chloroquinolin-3-yl)-3-(p-nitrophenyl)- 4,5-dihydropyrazol-1-yl)-4-(naphthalen-1- yl)thiazole (5e)}

Yield: $50 \%$; m.p.: $210{ }^{\circ} \mathrm{C}$; $\mathrm{R}_{\mathrm{f}}$ value: 0.68 ; IR (KBr): 1579, 1535, 1111; ${ }^{1} \mathrm{H}-\mathrm{NMR}: 3.60$ (d, $\mathrm{J}=17 \mathrm{~Hz}, 1 \mathrm{H}), 3.87(\mathrm{~d}, \mathrm{~J}=17 \mathrm{~Hz}, 1 \mathrm{H}), 5.18(\mathrm{~d}, \mathrm{~J}=18$ $\mathrm{Hz}, 1 \mathrm{H}), 7.14-8.12(\mathrm{~m}, 17 \mathrm{H}, \mathrm{Ar}-\mathrm{H}) ;{ }^{13} \mathrm{C}-\mathrm{NMR}$ : $37.5\left(\mathrm{C}_{4}\right.$ of the pyrazoline ring $), 53.4\left(\mathrm{C}_{5}\right.$ of the pyrazoline ring), $105.2\left(\mathrm{C}_{5}\right.$ of the thiazole ring), $121.1,123.4,124.3$ (2C), 124.6, 125.0 (3C), 125.3, 125.5, 125.7 (2C), 126.3 (3C), 127.9, $128.9,130.7,132.2,134.2,138.6,140.5,143.4$, $145.8,148.2,149.7\left(\mathrm{C}_{3}\right.$ of the pyrazoline ring $)$, $149.9\left(C_{5}\right.$ carbon of the quinoline ring $), 166.5\left(C_{2}\right.$ carbon of the thiazole ring); mass $(\mathrm{m} / \mathrm{z}): 561\left(\mathrm{M}^{+}\right.$, $100 \%), 562\left(\mathrm{M}^{+}+1\right), 281,188,141,113,94$; Elemental Analysis $\left(\mathrm{C}_{31} \mathrm{H}_{20} \mathrm{CIN}_{5} \mathrm{O}_{2} \mathrm{~S}\right)$ : Calcd.: C, 66.24; H, 3.58; N, 12.45; Found: C, 66.23; H, $3.55 ; \mathrm{N}, 12.45$.

\section{2-(3-(0-chlorophenyl)-5-(2-chloroquinolin-3- yl)-4,5-dihydropyrazol-1-yl)-4-(naphthalen-2- yl)thiazole (6a)}

Yield: $55 \%$; m.p.: $189{ }^{\circ} \mathrm{C}$; $\mathrm{R}_{\mathrm{f}}$ value: 0.73 ; IR $(\mathrm{KBr}): 1580,1538,1112 ;{ }^{1} \mathrm{H}-\mathrm{NMR}: 3.63$ (d, $\mathrm{J}=17 \mathrm{~Hz}, 1 \mathrm{H}), 3.90(\mathrm{~d}, \mathrm{~J}=17 \mathrm{~Hz}, 1 \mathrm{H}), 5.16(\mathrm{~d}$, $\mathrm{J}=18 \mathrm{~Hz}, 1 \mathrm{H}), 7.10-8.12(\mathrm{~m}, 17 \mathrm{H}, \mathrm{Ar}-\mathrm{H}) ;{ }^{13} \mathrm{C}-$ NMR: $37.0\left(\mathrm{C}_{4}\right.$ of the pyrazoline ring $), 53.4\left(\mathrm{C}_{5}\right.$ of the pyrazoline ring), $105.1 \quad\left(\mathrm{C}_{5}\right.$ of the thiazole ring), 124.2 (3C), 124.6, 125.0, 125.3 (3C), $125.5,125.6,126.1$ (2C), 126.8, 127.9, 128.1, $128.3,128.6,128.9,130.4(2 \mathrm{C}), 131.8,134.2$, $135.2,143.4,148.2,149.7\left(C_{3}\right.$ of the pyrazoline ring), $149.9\left(\mathrm{C}_{5}\right.$ carbon of the quinoline ring), $166.4\left(\mathrm{C}_{2}\right.$ carbon of the thiazole ring); mass $(\mathrm{m} / \mathrm{z}): 550\left(\mathrm{M}^{+}, 100 \%\right), 551\left(\mathrm{M}^{+}+1\right), 276,184$, 138, 111, 92; Elemental Analysis $\left(\mathrm{C}_{31} \mathrm{H}_{20} \mathrm{Cl}_{2} \mathrm{~N}_{4} \mathrm{~S}\right)$ :
Calcd.: C, 67.51; H, 3.65; N, 10.15; Found: C, $67.50 ; \mathrm{H}, 3.67 ; \mathrm{N}, 10.13$.

\section{2-(5-(2-chloroquinolin-3-yl)-3-(0- \\ fluorophenyl)-4,5-dihydropyrazol-1-yl)-4- (naphthalen-2-yl)thiazole (6b)}

Yield: 60 \%; m.p.: $214{ }^{\circ} \mathrm{C}$; $R_{f}$ value: 0.63; IR (KBr): 1576, 1537, 1110; ${ }^{1} \mathrm{H}-\mathrm{NMR}: 3.62$ (d, $\mathrm{J}=17 \mathrm{~Hz}, 1 \mathrm{H}), 3.88(\mathrm{~d}, \mathrm{~J}=17 \mathrm{~Hz}, 1 \mathrm{H}), 5.19(\mathrm{~d}$, $\mathrm{J}=18 \mathrm{~Hz}, 1 \mathrm{H}), 7.14-8.13(\mathrm{~m}, 17 \mathrm{H}$, Ar- $\mathrm{H}) ;{ }^{13} \mathrm{C}-$ NMR: $37.5\left(\mathrm{C}_{4}\right.$ of the pyrazoline ring), $53.4\left(\mathrm{C}_{5}\right.$ of the pyrazoline ring), $105.1\left(\mathrm{C}_{5}\right.$ of the thiazole ring), 113.3, 116.2, 122.4, 124.2 (3C), 124.6, 125.0, 125.3 (3C), 125.5 (2C), 126.1 (2C), 127.9, 128.8 (2C), $130.5(2 \mathrm{C}), 131.8,134.2,143.4$, 148.2, $149.7\left(\mathrm{C}_{3}\right.$ of the pyrazoline ring), 149.9 $\left(\mathrm{C}_{5}\right.$ carbon of the quinoline ring), 157.6, 166.6 $\left(\mathrm{C}_{2}\right.$ carbon of the thiazole ring); Mass $(\mathrm{m} / \mathrm{z}): 534$ $\left(\mathrm{M}^{+}, 100 \%\right), 535\left(\mathrm{M}^{+}+1\right), 268,179,134,107,90$; Elemental Analysis $\left(\mathrm{C}_{31} \mathrm{H}_{20} \mathrm{ClFN}_{4} \mathrm{~S}\right)$ : Calcd: $\mathrm{C}$, 69.58; H, 3.76; N, 10.46; Found: C: C, 69.55; H, $3.75 ; \mathrm{N}, 10.45$.

\section{2-(5-(2-chloroquinolin-3-yl)-3-(m- fluorophenyl)-4,5-dihydropyrazol-1-yl)-4- (naphthalen-2-yl)thiazole (6c)}

Yield: $50 \%$; m.p.: $178{ }^{\circ} \mathrm{C}$; $R_{f}$ value: 0.72 ; IR (KBr): 1580, 1540, 1108; ${ }^{1} \mathrm{H}-\mathrm{NMR}: 3.65$ (d, $\mathrm{J}=17 \mathrm{~Hz}, 1 \mathrm{H}), 3.91(\mathrm{~d}, \mathrm{~J}=17 \mathrm{~Hz}, 1 \mathrm{H}), 5.20(\mathrm{~d}$, $\mathrm{J}=18 \mathrm{~Hz}, 1 \mathrm{H}), \quad 7.10-8.15(\mathrm{~m}, 17 \mathrm{H}, \mathrm{Ar}-\mathrm{H}) ;{ }^{13} \mathrm{C}-$ NMR: $37.5\left(\mathrm{C}_{4}\right.$ of the pyrazoline ring), $53.4\left(\mathrm{C}_{5}\right.$ of the pyrazoline ring), $105.1\left(\mathrm{C}_{5}\right.$ of the thiazole ring), 113.0, 115.8, 121.8, 124.2 (3C), 124.6, 125.0, 125.3 (3C), 125.5, 125.6, 126.1 (2C), $127.9,128.4,128.9,130.5,131.8,133.6,134.2$, $143.4,148.2,149.7\left(C_{3}\right.$ of the pyrazoline ring), $149.9\left(\mathrm{C}_{5}\right.$ carbon of the quinoline ring), 161.0, $166.4\left(\mathrm{C}_{2}\right.$ carbon of the thiazole ring); Mass $(\mathrm{m} / \mathrm{z}): 534\left(\mathrm{M}^{+}, 100 \%\right), 535\left(\mathrm{M}^{+}+1\right), 268,179$, 134, 107, 90; Elemental Analysis $\left(\mathrm{C}_{31} \mathrm{H}_{20} \mathrm{ClFN}_{4} \mathrm{~S}\right)$ : Calcd.: C, 69.58; H, 3.76; N, 10.46; Found: C: C, 69.61; H, 3.75; N, 10.46.

\section{2-(5-(2-chloroquinolin-3-yl)-3-(p- fluorophenyl)-4,5-dihydropyrazol-1-yl)-4- (naphthalen-2-yl)thiazole (6d)}

Yield: $65 \%$; m.p.: $188{ }^{\circ} \mathrm{C}$; $R_{f}$ value: 0.70 ; IR (KBr): 1577, 1538, 1108; ${ }^{1} \mathrm{H}-\mathrm{NMR}: 3.62$ (d, $J=17 \mathrm{~Hz}, 1 \mathrm{H}), 3.89(\mathrm{~d}, \mathrm{~J}=17 \mathrm{~Hz}, 1 \mathrm{H}), 5.18(\mathrm{~d}$, $\mathrm{J}=18 \mathrm{~Hz}, 1 \mathrm{H}), 7.11-8.13(\mathrm{~m}, 17 \mathrm{H}$, Ar- $\mathrm{H}) ;{ }^{13} \mathrm{C}-$ NMR: $37.5\left(\mathrm{C}_{4}\right.$ of the pyrazoline ring), $53.4\left(\mathrm{C}_{5}\right.$ of the pyrazoline ring), $105.2\left(\mathrm{C}_{5}\right.$ of the thiazole ring), 114.6 (2C), 124.2 (3C), 124.6, 125.0, 125.3 (3C), 125.5 (2C), $126.1(2 \mathrm{C}), 127.5$ (2C), 127.9, $128.9,130.0,130.5,131.8,134.2,143.4,148.2$, $149.7\left(\mathrm{C}_{3}\right.$ of the pyrazoline ring $), 149.9\left(\mathrm{C}_{5}\right.$ carbon of the quinoline ring), 163.2, $166.5\left(\mathrm{C}_{2}\right.$ 
carbon of the thiazole ring); Mass (m/z): $534\left(\mathrm{M}^{+}\right.$, $100 \%), 535\left(\mathrm{M}^{+}+1\right), 268,179,134,107,90$; Elemental Analysis $\left(\mathrm{C}_{31} \mathrm{H}_{20} \mathrm{CIFN} \mathrm{N}_{4} \mathrm{~S}\right)$ : Calcd.: $\mathrm{C}$, 69.58; H, 3.76; N, 10.46; Found: C: C, 69.57; H, $3.75 ; \mathrm{N}, 10.46$.

\section{2-(5-(2-chloroquinolin-3-yl)-3-(p-nitrophenyl)- 4,5-dihydropyrazol-1-yl)-4-(naphthalen-2- yl)thiazole (6e)}

Yield: $55 \%$; m.p.: $196{ }^{\circ} \mathrm{C}$; $\mathrm{R}_{\mathrm{f}}$ value: 0.69 ; IR $(\mathrm{KBr}): 1578,1538,1109 ;{ }^{1} \mathrm{H}-\mathrm{NMR}: 3.61$ (d, $\mathrm{J}=17 \mathrm{~Hz}, 1 \mathrm{H}), 3.91(\mathrm{~d}, \mathrm{~J}=17 \mathrm{~Hz}, 1 \mathrm{H}), 5.20(\mathrm{~d}$, $\mathrm{J}=18 \mathrm{~Hz}, 1 \mathrm{H}), \quad 7.14-8.13(\mathrm{~m}, 17 \mathrm{H}, \operatorname{Ar}-\mathrm{H}) ;{ }^{13} \mathrm{C}-$ NMR: $37.5\left(\mathrm{C}_{4}\right.$ of the pyrazoline ring), $53.4\left(\mathrm{C}_{5}\right.$ of the pyrazoline ring), $105.1\left(\mathrm{C}_{5}\right.$ of the thiazole ring), $124.2(3 \mathrm{C}), 124.6,125.0(3 \mathrm{C}), 125.3(3 \mathrm{C})$, $125.5(2 \mathrm{C}), 125.7(2 \mathrm{C}), 126.1(2 \mathrm{C}), 127.9,128.9$, $130.5,131.8,134.2,140.5,143.4,148.2$ (2C), $149.7\left(\mathrm{C}_{3}\right.$ of the pyrazoline ring $), 149.9\left(\mathrm{C}_{5}\right.$ carbon of the quinoline ring), $165.5\left(\mathrm{C}_{2}\right.$ carbon of the thiazole ring); Mass $(\mathrm{m} / \mathrm{z}): 561\left(\mathrm{M}^{+}, 100 \%\right)$, $562\left(\mathrm{M}^{+}+1\right), 281,188,141,113$, 94; Elemental Analysis $\left(\mathrm{C}_{31} \mathrm{H}_{20} \mathrm{ClN}_{5} \mathrm{O}_{2} \mathrm{~S}\right)$ : Calcd.: $\mathrm{C}, 66.24 ; \mathrm{H}$, 3.58; N, 12.45; Found: C, 66.27; H, 3.55; N, 12.45 .

\section{Antimicrobial activity}

The data of the antimicrobial activity of the compounds (5a-5e and $6 a-6 e)$ obtained by serial plate dilution technique are listed in Table 1, Table 2 and Table 3, respectively.

Compound $6 \mathrm{~d} \quad(\mathrm{R}=4-\mathrm{F}$, naphthalen-2-yl derivative) exhibited MIC of $25 \mu \mathrm{g} / \mathrm{mL}$ and the highest activity of $100.60,92.01,101.37,91.85$, and $99.46 \%$ against $S$. aureus, E.faecalis, $S$. epidermidis, $B$. subtilis and $B$. cereus, respectively, in regard to the standard drug. Additionally, compound $\mathbf{6 d}$ exhibited the highest activity of $98.44,100.30,97.34$, and $103.45 \%$ against E.coli, K. pneumonia, B. bronchiseptica, and $P$. vulgaris respectively, in comparison to the standard drug. Compound $5 d \quad(R=4-F$, naphthalen-1-yl derivative) exhibited the highest activity of $99.75 \%$ with MIC of $25 \mu \mathrm{g} / \mathrm{mL}$ against $P$. aeruginosa with respect to the standard drug. The compound $5 d$ d $R=4-F$, naphthalen-1-yl derivative) displayed MIC value of $25 \mu \mathrm{g} / \mathrm{mL}$ and highest antifungal activity of 106.16, 96.50, 96.33, and $96.07 \%$ against Candida albicans, $A$. niger, A. flavus and $M$. purpureous, respectively, in comparison to standard drug. The compound 6d ( $R=4-F$, naphthalen-2-yl derivative) exhibited the highest activity of 96.50 and $103.80 \%$ against $A$. niger and $P$. citrinum, respectively.

\section{DISCUSSION}

The spectral data and elemental analysis of the titled compounds (5a-5e and 6a-6e) were in accordance with the assigned chemical structures. The disappearance of the characteristic IR peaks at about $3370 \mathrm{~cm}^{-1}$ to about $3442 \mathrm{~cm}^{-1}$ due to the $\mathrm{N}-\mathrm{H}$ group, and the peaks at about $1330 \mathrm{~cm}^{-1}$ to about $1340 \mathrm{~cm}^{-1}$ due to the $\mathrm{C}=\mathrm{S}$ groups present in the compounds (4a-4e) [23], supported the formation of the compounds (5a-5e and 6a-6e). The disappearance of signal of two amino protons of the compounds $(\mathbf{4 a - 4 e})$ at $\delta 8.44$ to 8.68 [23] also supported the formation of the compounds (5a-5e and 6a-6e).

It is also expected that these compounds might be exhibiting their antimicrobial effect by the same mechanism as has been reported for similar type of compounds. It has also been observed that the naphthalen-2-yl derivatives (6a-6e) produced better antimicrobial activity than the naphthalen-1-yl derivatives (5a-5e). The compounds (5a-5e and 6a-6e) were also found to be better antibacterial agents against Gram negative bacteria. This effect may be because of the presence of more aromatic groups that impart lipophilic character to the compounds. The structure activity relationship of the compounds $(5 a-5 e$ and $6 a-6 e)$ revealed that the presence of 4-F substituent in naphthalen-2-yl derivative (6d) and in naphthalen-1-yl derivative (5d) is required for superior antimicrobial activity against the gram positive bacteria, gram negative bacteria as well as fungi. The replacement of 4-F substituent with 4- $\mathrm{NO}_{2}$ substituent (6e) or with 2-F substituent (6b) or with $2-\mathrm{Cl}$ substituent (6a) provide compounds with lower antibacterial and antifungal potencies.

\section{CONCLUSION}

The findings for the synthesized compounds (5a$5 e$ and $6 a-6 e)$ indicate that the naphthalen-2-yl derivative $(\mathbf{6 d})$ with $4-F$ substituent in the phenyl ring yields more potent antimicrobial activity against $S$. aureus, $S$. epidermidis, $K$. pneumonia, $P$. vulgaris and $P$. citrinum. Compound $\mathbf{6 d}$ is a potential lead compound for further development, and therefore, needs to be tested against other microbial strains to confirm its broad spectrum antimicrobial activity.

\section{DECLARATIONS}

\section{Acknowledgement}

The authors are thankful to CDRI and Prince 
Sattam Bin Abdulaziz University for generating the spectral data of the title compounds.

\section{Conflict of Interest}

No conflict of interest associated with this work.

\section{Contribution of Authors}

The authors declare that this work was done by the authors named in this article and all liabilities pertaining to claims relating to the content of this article will be borne by them.

\section{Open Access}

This is an Open Access article that uses a funding model which does not charge readers or their institutions for access and distributed under the terms of the Creative Commons Attribution License (http://creativecommons.org/licenses/by/ 4.0) and the Budapest Open Access Initiative (http://www.budapestopenaccessinitiative.org/rea d), which permit unrestricted use, distribution, and reproduction in any medium, provided the original work is properly credited.

\section{REFERENCES}

1. Zowawi HM. Antimicrobial resistance in Saudi Arabia. Saudi Med J 2016; 37(9): 935-940.

2. Morgan DJ, Okeke IN, Laxminarayan R, Perencevich EN, Weisenberg $S$. Non-prescription antimicrobial use worldwide: a systematic review. Lancet Infect Dis 2011; 11: 692-701.

3. Harbarth $S$, Balkhy $H H$, Goossens $H$, Jarlier $V$, Kluytmans J, Laxminarayan $R$, Saam M, Belkum AV, Pittet D. Antimicrobial resistance: one world, one fight!. Antimicrob Resist Infect Control 2015; 4: 49. doi: 10.1186/s13756-015-0091-2.

4. Emeka PM, Al-Omar M, Khan TM. Public attitude and justification to purchase antibiotics in the Eastern region Al Ahsa of Saudi Arabia. Saudi Pharm J 2014; 22(6): 550-554.

5. Emeka PM, Al-Omar MJ, Khan TM. A qualitative study exploring role of community pharmacy in the irrational use and purchase of nonprescription antibiotics in $A$ I Ahsa. Eur J Gen Med 2012; 9(4): 230-234.

6. Khan TM, Ibrahim Y. A qualitative exploration of the nonprescription sale of drugs and incidence of adverse events in community pharmacy settings in the Eastern Province of the Kingdom of Saudi Arabia. Eur J Hosp Pharm Sci Pract 2013; 20(1): 26-31.

7. El Zowalaty ME, Belkina T, Bahashwan SA, El Zowalaty AE, Tebbens JD, Abdel-Salam HA, Khalil Al, Daghriry SI, Gahtani MA, Madkhaly FM, Nohi NI, Khodari RH, Sharahili RM, Dagreery KA, Khormi M, Habibah SA, Medrba BA, Gahtani AA, Hifthi RY, Zaid JM, Amshan
AW, Alneami AA, Noreddin A, Vlcek J. Knowledge, awareness, and attitudes toward antibiotic use and antimicrobial resistance among Saudi population. Int $J$ Clin Pharm 2016: 1-8. doi: 10.1007/s11096-016-0362-x.

8. Jindal AK, Pandya K, Khan ID. Antimicrobial resistance: A public health challenge. Med $J$ Armed Forces India 2015; 71(2): 178-181.

9. Bhatia R. Strategic approach to prevention and containment of antimicrobial resistance in South-East Asia. J Patient Saf Infec Cont 2013; 1(1): 19-21.

10. Brandt C, Makarewicz O, Fischer T, Stein C, Pfeifer $Y$, Werner G, Pletz MW. The bigger picture: the history of antibiotics and antimicrobial resistance displayed by scientometric data. Int J Antimicrob Agents 2014; 44(5): 424-430.

11. Kashyap SJ, Garg VK, Sharma PK, Kumar N, Dudhe R, Gupta JK. Thiazoles having diverse biological activities. Med Chem Res 2012; 21(8): 2123-2132.

12. Mishra $C B$, Kumari $S$, Tiwari M. Thiazole: A promising heterocycle for the development of potent CNS active agents. Eur J Med Chem 2015; 92(6): 1-34.

13. Marella A, Tanwar $O P$, Saha $R$, Ali MR, Srivastava $S$, Akhter M, Shaquiquzzaman M, Alam MM. Quinoline: A versatile heterocyclic. Saudi Pharm J 2013; 21(1): 1-12.

14. Kaur K, Jain M, Reddy RP, Jain R. Quinolines and structurally related heterocycles as antimalarials. Eur $J$ Med Chem 2010; 45(8): 3245-3264.

15. Alex JM, Kumar R. 4,5-Dihydro-1H-pyrazole: an indispensable scaffold. J Enzyme Inhib Med Chem 2014; 29(3): 427-442.

16. Marella A, Ali MR, Alam MT, Saha R, Tanwar O, Akhter M, Shaquiquzzaman M, Alam MM. Pyrazolines: a biological review. Mini Rev Med Chem 2013; 13(6): 921931.

17. Aggarwal R, Kumar S, Kaushik P, Kaushik D, Gupta GK. Synthesis and pharmacological evaluation of some novel 2-(5-hydroxy-5-trifluoromethyl-4,5-dihydropyrazol1-yl)-4-(coumarin-3-yl)thiazoles. Eur J Med Chem 2013; 62: 508-514.

18. Desai NC, Joshi VV, Rajpara KM, Vaghani HV, Satodiya HM. Synthesis of quinoline-pyrazoline based thiazole derivatives endowed with antimicrobial activity. Indian $\mathrm{J}$ Chem 2013; 52b: 1191-1201.

19. Imran M, Alam O, Abida. Synthesis and antimicrobial activity of some 2-Piperidinomethylamino-4-(7H/substitutedcoumarin-3-yl)-6-chlorosubstitutedphenyl pyrimidines. Trop J Pharm Res 2016; 15(9): 1955-1965.

20. Imran M, Abida, Alsalman AJ. Synthesis and evaluation of antimicrobial activity of some 2morpholinomethylamino-4-(7unsubstituted/substitutedcoumarin-3-yl)-6chlorosubstitutedphenyl pyrimidines. Trop $J$ Pharm Res 2016; 15(2): 393-404.

21. Imran M, Abida, Khan SA. Synthesis and antimicrobial activity of some 2-amino-4-(7substituted/unsubstitutedcoumarin-3-yl)-6(chlorosubstitutedphenyl)pyrimidines. Trop J Pharm Res 2015; 14(7): 1265-1272.

Trop J Pharm Res, May 2017; 16(5): 1154 
22. Imran M, Yar MS, Khan SA. Synthesis and antihyperglycemic activity of 2-(substitutedphenyl)-3-\{[4(1-naphthyl)-1,3-thiazol-2-yl] amino\}-4-oxo-1,3thiazolidin-5-ylacetic acid derivatives. Acta Pol Pharm 2009; 66(1): 51-56.

23. Barry AL. Procedures and theoretical considerations for testing antimicrobial agents in agar media. In: Lorian $V$,
Ed. Antibiotics in Laboratory Medicine, 3rd edn. Baltimore, Williams \& Wilkins; 1991; pp 1-16.

24. Varma $R S$, Khan ZK, Singh AP. Eds. Antifungal agents: past, present, future prospects. Lucknow: National Academy of Chemistry and Biology, India, 1998; pp 55128. 